\title{
Effect of Gama Irradiation of Bioethanol Producing Microorganisms on Bioethanol Formation from Sugarcane Bagasse and Potato Peels
}

\author{
A.A. Abdelhafez ${ }^{\#}$, T.S. El-Tayeb ${ }^{\#}$, T.M. El-Mongi* and Marwa \\ M. Moussa* \\ Department of Agricultural Microbiology, Faculty of Agriculture, \\ Ain Shams University, Shoubra El-Kheima and *Department of \\ Irradiation Microbiology, National Center for Radiation Research \\ \& Technology, Atomic Energy Authority, Cairo, Egypt.
}

7 HE PRESENT work was designed to investigate the production of bioethanol from agriculture feedstock (sugarcane bagasse and potato peels) using Saccharomyces cerevisiae ATCC 7754 and Zymomonas mobilis ATCC 29191, exposed to different doses of gamma irradiation $(0,100,300,500,1000$ and $1500 \mathrm{~Gy}$ ). The effect of different hydrolysis pretreatments of feedstock on resulting sugars (initial sugars), which were later fermented to bioethanol, was also tested and compared to non-hydrolyzed feedstock. Hydrolysis of sugarcane bagasse and potato peels was conducted with dilute sulphuric acid (2 and $6 \% \mathrm{v} / \mathrm{v}$ ), running at 100 and $120^{\circ} \mathrm{C}$ for 30 and $60 \mathrm{~min}$ of retention time. The highest bioethanol concentration obtained from sugarcane bagasse was $10.3 \mathrm{gL}^{-1}$, which was produced by Sacch. cerevisiae ATCC 7754 irradiated at 300 Gy from hydrolysate of $2 \%(\mathrm{v} / \mathrm{v}) \mathrm{H}_{2} \mathrm{SO}_{4}$ at $120^{\circ} \mathrm{C}$ for 60 min treatment. From the same treatment, the highest bioethanol concentration obtained by Z. mobilis ATCC 29191 was $4.4 \mathrm{gL}^{-1}$, when irradiated at $100 \mathrm{~Gy}$. This acid treatment produced $23.7 \mathrm{gL}^{-1}$ of sugars from the feedstock. The highest bioethanol concentration obtained from potato peels was $7.5 \mathrm{gL}^{-1}$, produced by Sacch. cerevisiae ATCC 7754 irradiated at $300 \mathrm{~Gy}$ from hydrolysate of $6 \%(\mathrm{v} / \mathrm{v}) \mathrm{H}_{2} \mathrm{SO}_{4}$ at $100^{\circ} \mathrm{C}$ for 60 min treatment, followed by $5.7 \mathrm{gL}^{-1}$ produced by Z. mobilis ATCC 29191 irradiated at 100 Gy. This treatment produced $24 \mathrm{gL}^{-1}$ of sugars from the feedstock.

Keywords: Saccharomyces cerevisiae ATCC 29191, Zymomonas mobilis ATCC 29191, Bioethanol, Feedstock, Gamma irradiation, Dilute acid hydrolysis.

With the growing crisis in fossil fuel and environmental pollution problems worldwide, bioethanol as a clean-burning renewable resource has become one of the most promising biofuels and many studies have been focused on improving the efficacy of the bioethanol production process. The production of bioethanol

\#Contact authors e-mails: tarekeltayeb@yahoo.com, aabdelhafez@yahoo.com 
from biomass materials received great attention in the worldwide. In the U.S., bioethanol is primarily produced from corn starch raw materials while in Brazil it is mainly produced from sugarcane juice and molasses. Together, these two countries account for $89 \%$ of the current global bioethanol production (Limayem \& Steven, 2012). Using less valuable materials, like lignocellulosic agricultural waste, could significantly reduce the production expense (Abo-State et al., 2013). lignocelluloses are mainly composed of cellulose, hemicellulose, and lignin. Cellulose chains interact with hemicellulose and lignin forming a lignin-carbohydrate complex, so that they must be pretreated and hydrolyzed by acid or base to produce sugars for bioethanol fermentation (Ferdian et al., 2012). Chemically, about $40-50 \%$ of the dry sugarcane bagasse residue is cellulose, much of which is in a crystalline structure. Another $25-35 \%$ is hemicelluloses. The remainder is mostly lignin plus lesser amounts minerals, waxes and other compounds (Jacobsen \& Wyman, 2002). Potato peel waste (PPW) contains sufficient quantities of starch, cellulose, hemicellulose, lignin and fermentable sugars to warrant use as an ethanol feedstock. Starch is a high yield feedstock for ethanol production, but its hydrolysis is required to produce bioethanol by fermentation (Arapoglou et al., 2010). Hydrolysis of sugarcane bagasse is crucial for the conversion of bagasse polysaccharides, mainly cellulose, into valuable products. However, the strong crystalline arrangement of cellulose and the protective effects by lignin and hemicelluloses makes it difficult for enzymes and acid catalysts to cleave the $\beta-1,4$ glycosidic bonds, which constitute a serious obstacle to hydrolysis (George et al., 2011).

Acid pretreatments normally aim for high yields of sugars from lignocellulosic materials; includes the use of sulfuric, nitric, or hydrochloric acids to remove hemicellulose components and expose cellulose for enzymatic digestion. The acid pretreatment can operate either under a high temperature and low acid concentration (dilute acid pretreatment) or under a low temperature and high acid concentration (concentrated acid pretreatment) (Karimi et al., 2006).

Gamma irradiation is electromagnetic radiation high-energy with short wavelength, emitted by radioactive isotopes (cobalt-60 or cesium-137) as the unstable nucleus breaks up and decays to reach a stable form. It is widely used for sterilization of medical devices, food preservation and processing of tissue and blood components, obviating the need for high temperatures that can be damaging to such products (Osterholm \& Norgan, 2004). The biological effects of ionizing radiation on cells is due to both direct interactions with critical cell components and indirect actions on these targets by molecular entities formed because of the radiolysis of other molecules in the cell, particularly by radicals formed from water. Ionizing radiation is capable of causing a variety of chemical changes in microorganisms, of which DNA is the most critical target of ionizing radiation (Al-Sudany et al., 2010 and Grecz et al., 1983). The low doses of gamma irradiation may enhance the activity of microorganisms in biological processes. Sacch. cerevisiae strains, exposed to low doses (>100 Gy) of gamma irradiation, showed increased activity of alcohol-dehydrogenase enzyme (Atia, 2005; Chakravarty \& Sen, 2001 and Akacha et al., 2008).

Egypt. J. Microbiol. 49 (2014) 
The aim of this work was to study the effect of different doses of gamma irradiation on some bioethanol producing microbes (Saccharomyces cerevisiae ATCC 7754 or Zymomonas mobilis ATCC 29191) with or without dilute acid hydrolysis of sugarcane bagasse and potato peels and the effect of these treatments on bioethanol production.

Materials

\section{Materials and methods}

Microorganisms for bioethanol production

Saccharomyces cerevisiae ATCC 7754 and Zymomonas mobilis ATCC 29191 were obtained from The Microbiological Resources Center (Cairo MIRCEN), Faculty of Agriculture, Ain Shams Univeristy, Cairo, Egypt.

Agro-industrial feedstock

Sugarcane bagasse was obtained from sugar cane juice shop and potato peels was obtained from local food restaurants, both located in Shibin Al Qanatir, Al Qalyubiya, Egypt. Both sugarcane bagasse and potato peels were sun-dried then milled using a laboratory hammer mill (Retsch $\mathrm{GmbH} \& \mathrm{Co}$. KG, Germany) to pass through $1 \mathrm{~mm}$ screen. These feedstock were homogenized and oven-dried at $45^{\circ} \mathrm{C}$ prior to chemical analysis and pretreatment assays. The dried materials were stored in airtight containers at room temperature before use.

Media used

YM medium (Wickerham, 1946) was used for cultivation, maintenance and seed culture of Sacch. cerevisiae ATCC 7754 with the following ingredients $\left(\mathrm{gL}^{-1}\right)$ : Yeast extract 3; malt extract 3; glucose 10; peptone 5; agar 15; pH $6.0 \pm 0.2$. ATCC medium 948 (Swings \& Deley, 1977) was used for cultivation, maintenance and seed culture of Z. mobilis ATCC 29191 with the following ingredients $\left(\mathrm{gL}^{-1}\right)$ : Glucose 20; yeast extract 5; agar 15; pH $6.5 \pm 0.2$.

Methods

Analysis of agro-industrial feedstock

Determination of moisture content: Five grams of each feedstock were dried in oven at $45^{\circ} \mathrm{C}$ overnight and left to cool in a desicator then weighed until reach a constant weight. Moisture content of each sample was calculated (George et al., 2011).

Determination of total sugars: Total sugars were determined before and after hydrolysis treatments of sugarcane bagasse and potato peels. Total sugars were extracted according to the method reported by Pak \& Simon (2004) and the supernatants were used for sugar analysis. Total sugars analysis was determined by the Phenol-sulfuric acid method (Dubois et al., 1956 and Pak \& Simon, 2004).

Carbon and nitrogen content of feedstock: Carbon content of sugarcane bagasse and potato peels were determined according to Tiessen \& Moir (1993). Nitrogen content of sugarcane bagasse and potato peels were determined according to Stuart (1936). 
Irradiation of microorganisms

Effect of gamma irradiation on bioethanol production was investigated by exposing the producing microorganisms to gamma " $\gamma$ " radiation using (Indian cobalt-60 gamma cell at the National Center for Radiation Research and Technology, Egyptian Atomic Energy Authority "EAEA", Cairo, Egypt). For the irradiation of microorganisms, plates containing colonies of Sacch. cerevisiae ATCC 7754 grown on YM agar and colonies of Z. mobilis on ATCC 948 agar were exposed to doses of $\gamma$-radiation as follow: 0, 100, 300, 500, 1000, 1500, 2000, 2500 and 3000 Gy (Gy: Gray is a measurement unit of absorbed dose of gamma radiation, exposure for $1 \mathrm{~min}=43.8 \mathrm{~Gy}$ ) (Thornley, 1963). To determine The D10-value (the dose required to inactivate $90 \%$ of a population), the exposed cells were serially diluted in sterile isotonic saline solution and $0.1 \mathrm{ml}$ suspension of appropriate dilutions was spread on solid YM or ATCC 948 media, incubated at $30^{\circ} \mathrm{C}$ for $48 \mathrm{~h}$, and the growing colonies were counted. A dose response curve was drawn by plotting the dose (Gy) against log of surviving cells. Surviving colonies resulted after each gamma irradiation dose was plotted on a logarithmic scale as a function of gamma irradiation dose, resulting in survivor curves. The Surviving colonies were tested for bioethanol production. The D10-value was calculated using the following equation (Thornley, 1963).

$$
\mathrm{D} 10=\frac{\operatorname{Dose}(\mathrm{D})}{\log \mathrm{No}-\log \mathrm{N}}
$$

where "D" irradiation dose, "No" initial count and "N" the count at specific dose.

Feedstock processing

Bioethanol production from feedstock consisted of two main stages, first: feedstock pretreatment and second: bioethanol production. Feedstock pretreatment was performed by dilute acid hydrolysis. Bioethanol production was performed using neutralized (to $\mathrm{pH}$ 5.8) pretreated feedstock, on which Sacch. cerevisiae ATCC 7754 and Z. mobilis ATCC 29191 were inoculated to ferment released sugars into alcohol.

Dilute acid hydrolysis

To determine the effect of acid concentration, retention time and hydrolysis temperature, 5 grams of feedstock were added to $250 \mathrm{ml}$ Erlenmeyer flask containing $95 \mathrm{ml}$ of $2 \%$ or $6 \%(\mathrm{v} / \mathrm{v})$ of sulphuric acid $(98 \%)$ or $95 \mathrm{ml}$ of tap water (the control treatment), $6.7 \pm 0.2$ (using $\mathrm{pH}$ meter EPH211-Hanna Instruments Inc). Hydrolysis was run at either 100 or $120^{\circ} \mathrm{C}$ and the reaction time was 30 or 60 min (Pattana et al., 2010). The pretreated sugarcane bagasse and potato peels were left to cool then filtered to remove the solid fraction and the sugar-rich liquid filtrate was neutralized, as follows: the $\mathrm{pH}$ of the separated hydrolyzate was adjusted to 5.8 in two steps, first by $\mathrm{NaOH}$ pellets to $\mathrm{pH}=3$ and second by ammonia solution $(33 \%)$ to $\mathrm{pH}=5.8$. 


\section{Bioethanol fermentation}

Before sterilization, neutralized hydrolyzate was supplemented with the following nutrients $\left(\mathrm{gL}^{-1}\right): \mathrm{KH}_{2} \mathrm{PO}_{4} 2, \mathrm{MgSO}_{4} .7 \mathrm{H}_{2} \mathrm{O} 1$ and $\left(\mathrm{NH}_{4}\right)_{2} \mathrm{SO}_{4} 1$ (Davis et al., 2009) for Z. mobilis ATCC 29191 and yeast extract 3, peptone 3.5, $\mathrm{KH}_{2} \mathrm{PO}_{4} 2$, $\mathrm{MgSO}_{4} \cdot 7 \mathrm{H}_{2} \mathrm{O} 1$ and $\left(\mathrm{NH}_{2}\right)_{2} \mathrm{SO}_{4} 1$ for Sacch. cerevisiae ATCC 7754 (Arapoglou et al., 2010). After that, hydrolyzate was autoclaved at $121^{\circ} \mathrm{C}$ for $20 \mathrm{~min}$ and used for bioethanol production. Flasks containing $95 \mathrm{ml}$ of neutralized sterilized acid-hydrolyzates feedstock or sterilized non-hydrolyzed (control), were inoculated with $5 \mathrm{ml}$ of $48 \mathrm{~h}$ old liquid seed cultures of Sacch. cerevisiae ATCC 7754 or Z. mobilis ATCC 29191. Flasks were incubated in anaerobic incubator (Labconco Manufacturing Corp., USA) at $30 \pm 2^{\circ} \mathrm{C}$ for 4 days. After incubation, bioethanol was extracted by transferring $100 \mathrm{ml}$ of the grown culture to a rotary evaporator (R206D 2L-SENCO) and the apparatus was run for 10-20 min at $78.5^{\circ} \mathrm{C}$. The distillate was used to determine bioethanol concentration as described later. Standard inoculum (seed culture) of each organism was prepared by inoculating test tubes containing $5 \mathrm{ml}$ broth media of YM (for Sacch. cerevisiae ATCC 7754 cultivation) or ATCC 948 (for Z. mobilis ATCC 29191 cultivation) with a full loop of tested culture and incubated at $30^{\circ} \mathrm{C}$ for $48 \mathrm{~h}$. All tests were performed in triplicates.

\section{Bioethanol determination}

Distillate obtained from rotary evaporator was used to determine bioethanol concentration colorimetrically using potassium dichromate method (Crowell \& Ough, 1979).

Determination of viable cells count

Viable cells count of both organisms was carried out by plate count method (Talyour, 1962).

Bioethanol production parameters

According to Gamal et al. (1991):

$$
\begin{aligned}
& \text { Conversion coefficient }(\%)=\frac{\text { Bioethanol concentration produced }\left(\mathrm{g} \mathrm{L}^{-1}\right)}{\text { Consumed sugars }\left(\mathrm{g} \mathrm{L}^{-1}\right)} \times 100 \\
& \text { Bioethanol yield }(\% \mathrm{w} / \mathrm{w})=\frac{\text { Bioethanol concentration produced }\left(\mathrm{g} \mathrm{L}^{-1}\right)}{\text { Initial sugars }\left(\mathrm{g} \mathrm{L}^{-1}\right)} \times 100
\end{aligned}
$$

Sugar utilizing efficiency $(\% \mathrm{w} / \mathrm{w})$

According to Ramadan et al. (1985): 
Sugar utilizing efficiency $(\% \mathrm{w} / \mathrm{w})=\frac{\text { Consumed sugars }\left(\mathrm{g} \mathrm{L}^{-1}\right)}{\text { Initial sugars }\left(\mathrm{g} \mathrm{L}^{-1}\right)} \times 100$

Statistical analysis

Data was analyzed by the method of (SAS, 1996). Differences between means were compared using Duncan's Multiple Range Test according to Duncan (1955).

\section{Results and Discussion}

Analysis of agro-industrial feedstock

The analysis of sugarcane bagasse and potato peels are shown in Table 1. For sugarcane bagasse and potato peels, the moisture content was $16.7 \%(\mathrm{w} / \mathrm{w})$ and $22.2 \%(\mathrm{w} / \mathrm{w})$, total carbon was $41 \%(\mathrm{w} / \mathrm{w})$ and $38 \%(\mathrm{w} / \mathrm{w})$, total nitrogen was $0.52 \%(\mathrm{w} / \mathrm{w})$ and $0.69 \%(\mathrm{w} / \mathrm{w})$ and $\mathrm{C} / \mathrm{N}$ ratio was 79 and 55, respectively.

TABLE 1. Analysis of raw sugarcane bagasse and potato peels.

\begin{tabular}{|l|c|c|c|c|}
\hline \multicolumn{1}{|c|}{ Feedstock } & $\begin{array}{c}\text { Moisture content } \\
(\mathbf{w} / \mathbf{w} \%)\end{array}$ & $\begin{array}{c}\text { Total carbon } \\
(\mathbf{w} / \mathbf{w} \%)\end{array}$ & $\begin{array}{c}\text { Total nitrogen } \\
(\mathbf{w} / \mathbf{w} \%)\end{array}$ & C/N ratio \\
\hline Sugarcane bagasse & $16.7 \pm 3.04$ & $41 \pm 1.04$ & $0.52 \pm 0.03$ & 79 \\
\hline Potato peels & $22.2 \pm 5.02$ & $38 \pm 2.02$ & $0.69 \pm 0.01$ & 55 \\
\hline
\end{tabular}

Effect of gamma irradiation on bioethanol production

Throughout this work, the effect of gamma irradiation was examined on bioethanol producing organisms to enhance the bioethanol production process. Two locally available low-price agricultural wastes, sugarcane bagasse and potato peels, were used for bioethanol production by Sach. cerevisiae ATCC 7754 and Zymomonas mobilis ATCC 29191 in batch culture process.

Effect of gamma irradiation of bioethanol producing organisms to ferment nonhydrolyzed feedstock

In this study, gamma irradiated Sacch. cerevisiae ATCC 7754 and Zymomonas mobilis ATCC 29191 were used for bioethanol production from non-hydrolyzed sugarcane bagasse and potato peels. Firstly, the effect of exposing these two organisms to different gamma irradiation doses $(0,100,300$, $500,1000,1500,2000,2500$ and $3000 \mathrm{~Gy}$ ) was tested on the growth of these organisms. Z. mobilis ATCC 29191 and Sacch. cerevisiae ATCC 7754 were exposed to its specific sublethal dose, which are known to be $3000 \mathrm{~Gy}$ for both organisms. The radiation resistance of Z. mobilis ATCC 29191 and Sacch. cerevisiae ATCC 7754 was expressed as $\mathrm{D}_{10}$ value obtained from the dose response curves which were drown. Both organisms were lethally affected by increasing irradiation dose up to $3000 \mathrm{~Gy}$. Thus, the range of doses was

Egypt. J. Microbiol. 49 (2014) 
narrowed to end at $1500 \mathrm{~Gy}$ for next experiment. Within the range of 0,100 , 300, 500, 1000 and $1500 \mathrm{~Gy}$, microbial growth, sugars consumption and bioethanol production, were determined to get correlation between irradiation dose and bioethanol production to select the suitable irradiation treatment. Data presented in Table 2 show that cells growth of both organisms decreased with increasing irradiation dose, regardless of the feedstock type. Therefore, the highest cells count was recorded in the non-irradiated Sacch. cerevisiae ATCC $7754\left(33.8 \times 10^{4} \mathrm{CFU} / \mathrm{ml}\right)$ while it was $29.2 \times 10^{4} \mathrm{CFU} / \mathrm{ml}$ for the non-irradiated cells $Z$. mobilis. When comparing between the two feedstocks, concentration of the initial total sugars in productive media (Table 2, footnote) obtained by sugarcane bagasse was significantly higher $\left(14.2 \mathrm{gL}^{-1}\right)$ than that obtained from potato peels $\left(6.7 \mathrm{gL}^{-1}\right)$, which should explain the difference between the two feedstock in bioethanol production by either organisms.

Regarding the effect of gamma irradiation on the organism productivity of bioethanol, irradiation of Z. mobilis ATCC 29191 significantly reduced final bioethanol concentration from $3 \mathrm{gL}^{-1}$ (non-irradiated) down to $1.8 \mathrm{gL}^{-1}$ (at 150 $\mathrm{Gy}$ ) in case of sugarcane bagasse, and from $2 \mathrm{gL}^{-1}$ (non-irradiated) to $1 \mathrm{gL}^{-1}$ (at 1500 Gy) in case of potato peels. Sacch. cerevisiae ATCC 7754 had different response to irradiation, that its productivity from sugarcane bagasse increased from $4.2 \mathrm{~g} \mathrm{~L}^{-1}$, when non-irradiated to reach $4.9 \mathrm{gL}^{-1}$, when exposed to $300 \mathrm{~Gy}$, then decreased with more irradiation to reach $3 \mathrm{gL}^{-1}$, when exposed to $1500 \mathrm{~Gy}$. Moreover, its productivity of bioethanol from potato peels increased only from $2.2 \mathrm{~g} \mathrm{~L}^{-1}$, at $0 \mathrm{~Gy}$, to $2.4 \mathrm{gL}^{-1}$, at $100 \mathrm{~Gy}$, then decreased thereafter down to 1.2 $\mathrm{gL}^{-1}$, at $1500 \mathrm{~Gy}$. The highest bioethanol concentration $\left(4.9 \mathrm{gL}^{-1}\right)$ was obtained from sugar cane bagasse when fermented with Sacch. cerevisiae ATCC 7754 irradiated at $300 \mathrm{~Gy}$, where the bioethanol yield, conversion coefficient and sugar utilization efficiency were $34.5 \%(\mathrm{w} / \mathrm{w}), 45.7 \%(\mathrm{w} / \mathrm{w})$ and $75.4 \%(\mathrm{w} / \mathrm{w})$, respectively.

From the foregoing results, it could be concluded that the production of bioethanol by either Sacch. cerevisiae ATCC 7754 or Z. mobilis ATCC 29191 on both non-hydrolyzed sugarcane bagasse and potato peels was not satisfying, which could be attributed to the lower sugar content in non-hydrolyzed sugarcane bagasse or potato peels. Furthermore, the following experiments were conducted to increase the role of irradiation on bioethanol production process. On the contrary, Gunasekaran \& Chandra (2007) noticed that the maximum bioethanol yields produced by Z. mobilis from cassava peels and sweet potato peels were $23 \%(\mathrm{w} / \mathrm{w})$ and $12 \%(\mathrm{w} / \mathrm{w})$, respectively, while it was $22 \%(\mathrm{w} / \mathrm{w})$ and $12 \%(\mathrm{w} / \mathrm{w})$, respectively, when produced by Sacch. cerevisiae, which reveals a higher bioethanol production by Z. mobilis than Sacch. cerevisiae. On the other hand, Carvalho (2009) reported that using sugarcane bagasse directly without pretreatment gave a slow and low biogas yield. Therefore, the pretreatment of residues was needed. 

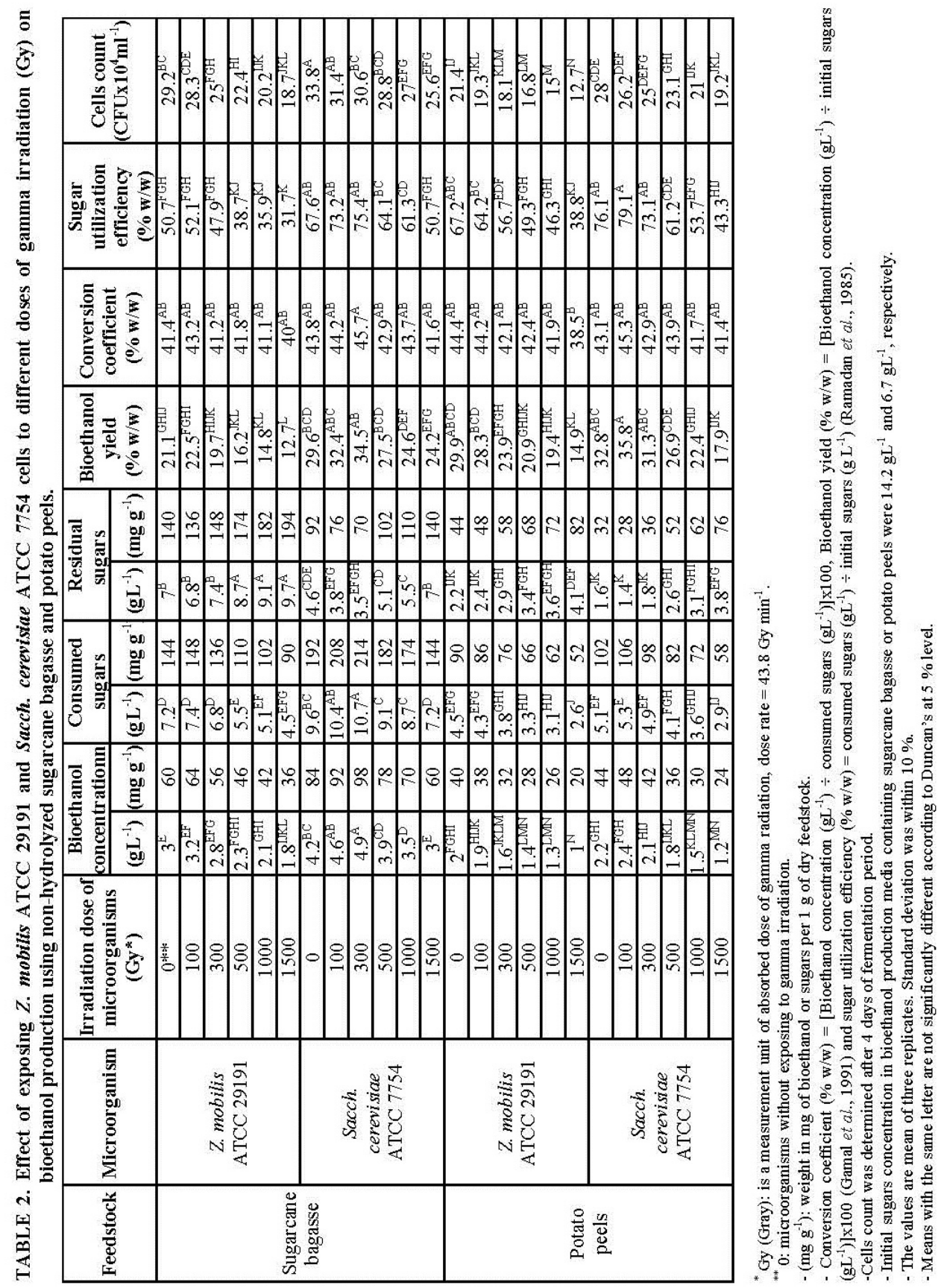
Effect of gamma irradiation of bioethanol producing organisms on bioethanol production from acid-hydrolyzed feedstock

Acid-hydrolyzed sugarcane bagasse

Acid hydrolysis of sugarcane bagasse was performed using 2 or $6 \%(\mathrm{v} / \mathrm{v})$ $\mathrm{H}_{2} \mathrm{SO}_{4}$ at $100^{\circ} \mathrm{C}$ or $120^{\circ} \mathrm{C}$ for 30 or 60 min of retention time. The neutralized nutrients-amended acid hydrolyzates of sugarcane bagasse was used as basal media to study the effect of gamma irradiation (as conducted in previous experiment) on bioethanol production by either Z. mobilis ATCC 29191 or Sacch. cerevisiae ATCC 7754 during 4 days of incubation at $30^{\circ} \mathrm{C}$. Table 3 illustrates results of acid hydrolysis treatment of sugarcane bagasse with $2 \%$ (v/v) $\mathrm{H}_{2} \mathrm{SO}_{4}$ at $100^{\circ} \mathrm{C}$ for 30 and $60 \mathrm{~min}$. Compared with non-hydrolyzed treatment, this treatment increased the initial sugars concentration to $15.7 \mathrm{gL}^{-1}$ when hydrolysis was run for $30 \mathrm{~min}$ and $18.5 \mathrm{gL}^{-1}$, when hydrolysis was run for $60 \mathrm{~min}$ (see footnote of Table 3). However, bioethanol yield was higher in 30 min treatment than $60 \mathrm{~min}$, by both organisms, and regardless of which organism was used and irradiation dose.

Overall performance of Sacch. cerevisiae ATCC 7754 in producing bioethanol from bagasse was significantly higher in both treatments of retention times than Z. mobilis ATCC 29191, regardless of irradiation treatment. Exposing Z. mobilis ATCC 29191 to irradiation caused insignificant increase in bioethanol concentration whereas irradiating Sacch. cerevisiae ATCC 7754 caused significant increase in bioethanol production up to $300 \mathrm{~Gy}$, where $5.5 \mathrm{gL}^{-1}$ were obtained from 30min hydrolysis treatment, giving bioethanol yield of $35 \% \mathrm{w} / \mathrm{w}$, conversion coefficient of $46.2 \% \mathrm{w} / \mathrm{w}$ and sugar utilization efficiency of $74 \%$ $(\mathrm{w} / \mathrm{w})$. Increasing the irradiation dose over this limit greatly decreased the final bioethanol concentration. The same trend for Sacch. cerevisiae ATCC 7754 was observed in $60 \mathrm{~min}$ hydrolysis treatment, expect for lower values, where final bioethanol concentration was $4.8 \mathrm{gL}^{-1}$ when using Sacch. cerevisiae ATCC 7754 irradiated at $300 \mathrm{~Gy}$, giving $26 \%$ (w/w) of bioethanol yield, $43.6 \%$ (w/w) for conversion coefficient and $59.5 \%(\mathrm{w} / \mathrm{w})$ for sugar utilization efficiency.

It is also important to mention that at this level of irradiation, cell count of Sacch. cerevisiae was not at its best, where it was significantly lower than nonirradiated culture, which means that the organism's performance was positively affected by the irradiation, despite the decrease in cell number. The best result of bioethanol production was obtained from 30 min hydrolysis treatment where it showed $5.5 \mathrm{gL}^{-1}$ of bioethanol concentration. Cell counts of both organisms were negatively affected by irradiation, where the best count was recorded in the nonirradiated culture of Sacch. cerevisiae ATCC 7754 (31.4 x 10 $\left.\mathrm{CFU} \mathrm{ml}^{-1}\right)$, while

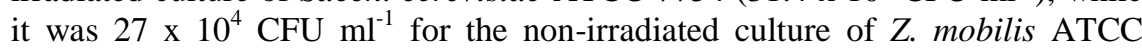
29191. In all treatments, Sacch. cerevisiae ATCC 7754 had higher cell counts than Z. mobilis ATCC 29191. These results are in line with those obtained by Abdel-Fattah et al. (2000) who reported that exposing Sacch. cerevisiae ATCC 7754 cells to gamma irradiation increased its ability to grow and produce higher ethanol yield in stress conditions. 


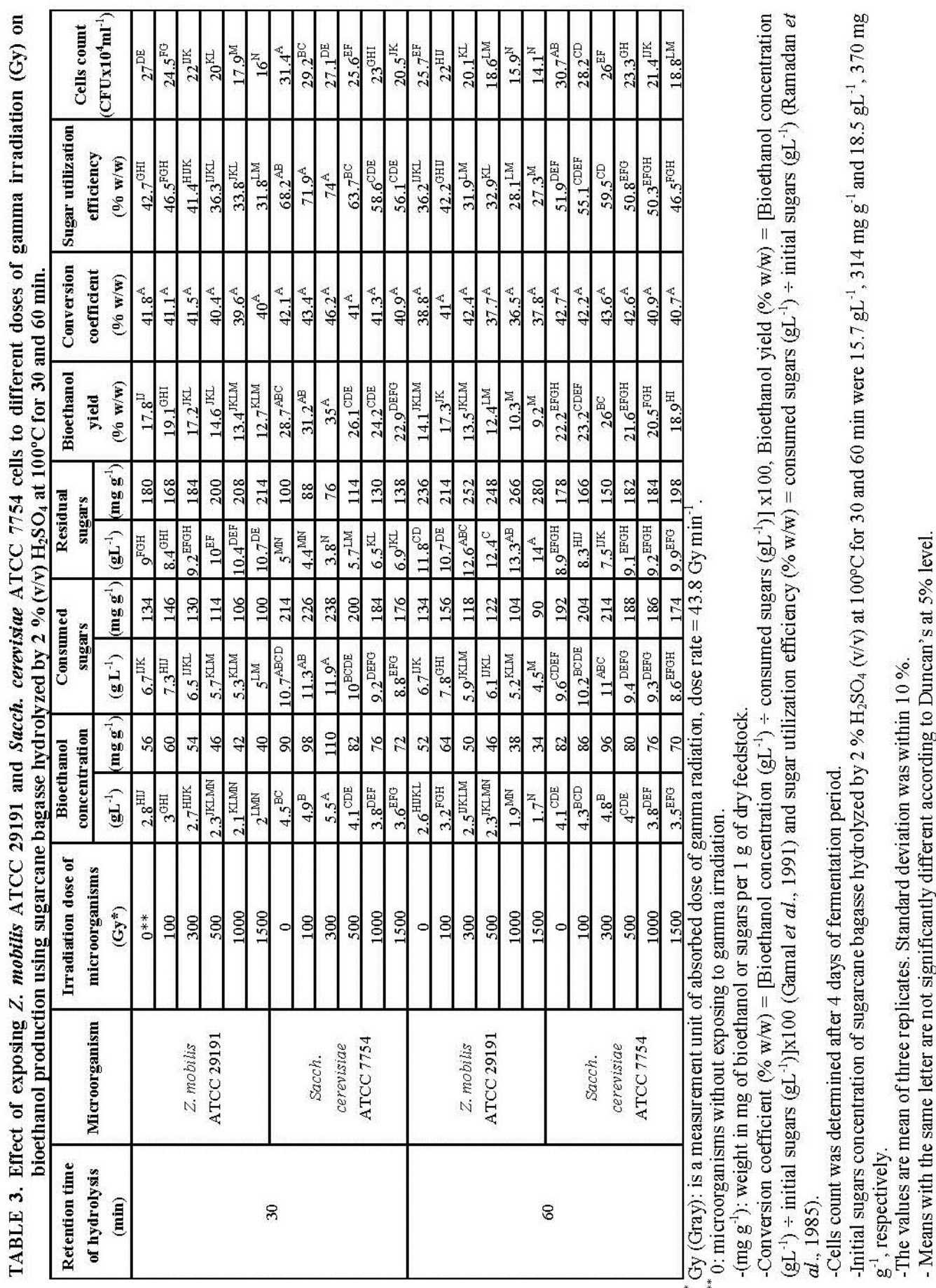

Egypt. J. Microbiol. 49 (2014) 
Increasing hydrolysis temperature to $120^{\circ} \mathrm{C}$ with $2 \%$ (v/v) $\mathrm{H}_{2} \mathrm{SO}_{4}$ for $30 \mathrm{~min}$ and $60 \mathrm{~min}$ increased the initial sugars concentration obtained from sugarcane bagasse to $20.2 \mathrm{gL}^{-1}$ and $23.7 \mathrm{gL}^{-1}$, respectively (Table 4 , footnote). In the 30 min hydrolysis run, the highest bioethanol concentrations obtained from sugarcane bagasse by Z. mobilis ATCC 29191 was $3.9 \mathrm{gL}^{-1}$ when irradiated at 100 Gy, while that obtained by Sacch. cerevisiae ATCC 7754 was $7.3 \mathrm{gL}^{-1}$, when irradiated at $300 \mathrm{~Gy}$. When hydrolysis was run at the same temperature for $60 \mathrm{~min}$, bioethanol concentration obtained by Sacch. cerevisiae ATCC 7754 (irradiated at $300 \mathrm{~Gy}$ ) significantly increased to $10.3 \mathrm{gL}^{-1}$, and the bioethanol yield and conversion coefficient and sugar utilization efficiency were $44.7 \%$ (w/w), $46.8 \%(\mathrm{w} / \mathrm{w})$ and $92.8 \%(\mathrm{w} / \mathrm{w})$, respectively (Table 4). Increasing the irradiation dose over 300 Gy greatly decreased the final bioethanol concentration from Sacch. cerevisiae ATCC 7754. In the same hydrolysis run, Z. mobilis ATCC 29191 was only able to produce $4.4 \mathrm{gL}^{-1}$ of bioethanol, when irradiated at $100 \mathrm{~Gy}$. The highest cells count was recorded in the non-irradiated culture of Sacch. cerevisiae ATCC $7754\left(31 \times 10^{4} \mathrm{CFU} \mathrm{ml}^{-1}\right)$, while it was $24.4 \times 10^{4} \mathrm{CFU}$ $\mathrm{ml}^{-1}$ for the same treatment of Z. mobilis ATCC 29191. In all treatments, Sacch. cerevisiae ATCC 7754 gave higher cell counts than Z. mobilis ATCC 29191.

These results are in partial agreement with those reported by Aguilar et al. (2002) who found that the best acid hydrolysis treatment of sugarcane bagasse was $2 \%(\mathrm{v} / \mathrm{v}) \mathrm{H}_{2} \mathrm{SO}_{4}$ at $122^{\circ} \mathrm{C}$ for 24 min which hydrolyzed around $90 \%$ of hemicellulose to xylose and glucose $\left(21.6 \mathrm{gL}^{-1}\right.$ and $3 \mathrm{gL}^{-1}$, respectively). They also detected low concentration of by-products (furfural and acetic acid) and low degradation of the cellulose fraction.

Hydrolysis of sugarcane bagasse with $6 \%(\mathrm{v} / \mathrm{v}) \mathrm{H}_{2} \mathrm{SO}_{4}$ at $100^{\circ} \mathrm{C}$ for 30 and $60 \mathrm{~min}$ increased the initial released sugars concentration to $27.2 \mathrm{gL}^{-1}$ and 28.6 $\mathrm{gL}^{-1}$, respectively (Table 5, footnote). However, final bioethanol concentration decreased in almost all treatments inoculated by Z. mobilis ATCC 29191 and Sacch. cerevisiae ATCC 7754, which could be attributed to the formation of furfural and hydroxymethylfurfural (HMF), which are known as the most important inhibitors during fermentation of dilute-acid hydrolyzates.

The highest final bioethanol concentration from sugarcane bagasse $\left(6.9 \mathrm{gL}^{-1}\right)$ was obtained by Sacch. cerevisiae ATCC 7754 irradiated at 300 Gy from $60 \mathrm{~min}$ hydrolysis treatment (compared to $10.3 \mathrm{gL}^{-1}$, obtained by the same irradiation treatment of Sacch. cerevisiae ATCC 7754 but using bagasse hydrolyzed by $2 \%$ (v/v) $\mathrm{H}_{2} \mathrm{SO}_{4}$ at $100^{\circ} \mathrm{C}$ for $60 \mathrm{~min}$ ). In this treatment, the bioethanol yield, conversion coefficient and sugar utilization efficiency were $24.1 \%(\mathrm{w} / \mathrm{w}), 44.8 \%$ $(\mathrm{w} / \mathrm{w})$ and $53.8 \%(\mathrm{w} / \mathrm{w})$, respectively. On the other hand, the highest final bioethanol concentration obtained by Z. mobilis ATCC 29191 was $3.4 \mathrm{gL}^{-1}$, from $100 \mathrm{~Gy}$ treatment and utilizing sugarcane bagasse hydrolyzed for $60 \mathrm{~min}$. In this treatment, the bioethanol yield, conversion coefficient and sugar utilization efficiency were $12.5 \%(\mathrm{w} / \mathrm{w}), 45.3 \%(\mathrm{w} / \mathrm{w})$ and $26.8 \%(\mathrm{w} / \mathrm{w})$, respectively (Table 5). 


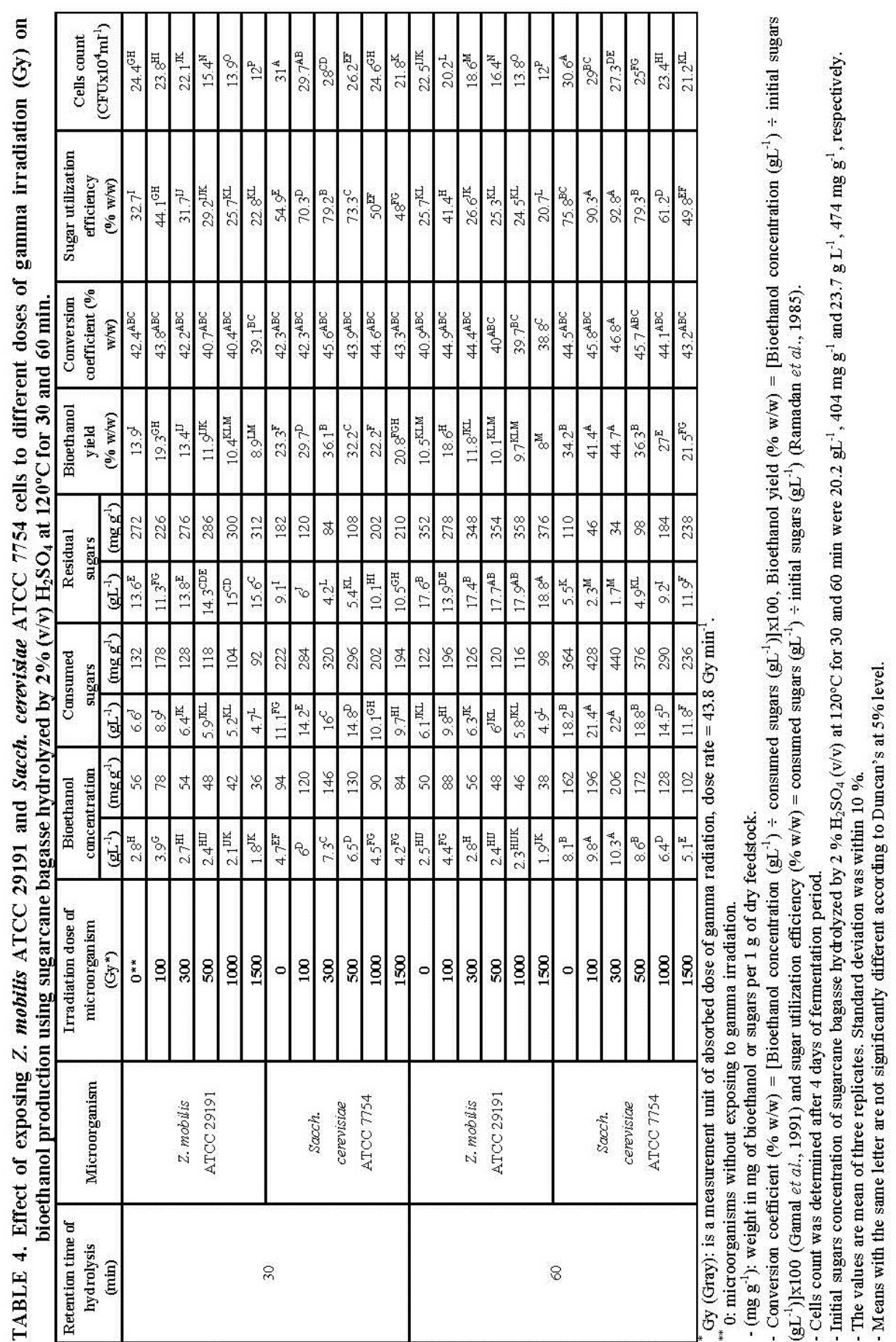




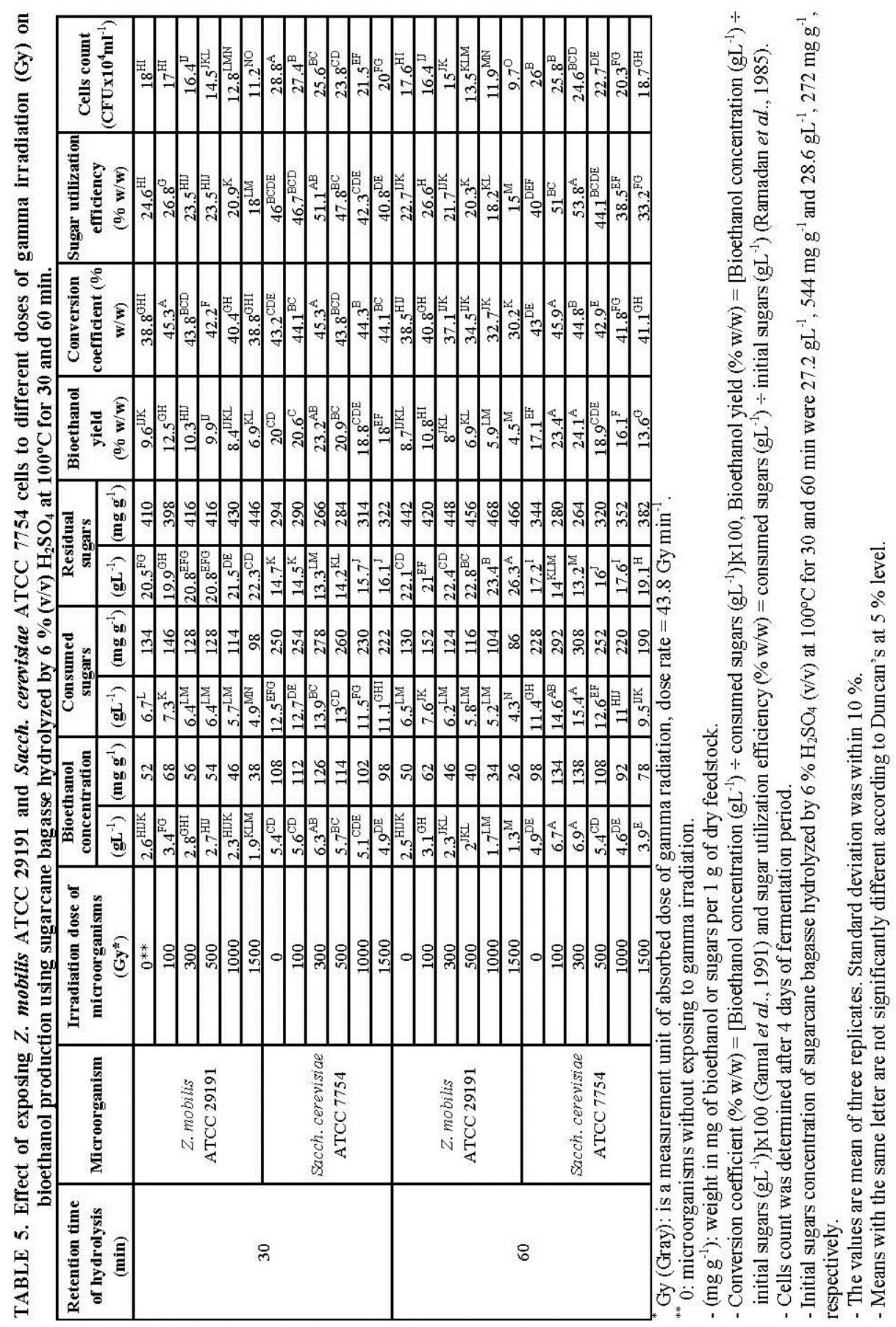


Results of increasing hydrolysis temperature to $120^{\circ} \mathrm{C}$ are illustrated in Table 6 . Hydrolysis with $6 \%(\mathrm{v} / \mathrm{v}) \mathrm{H}_{2} \mathrm{SO}_{4}$ at $120^{\circ} \mathrm{C}$ for 30 and 60 min increased the initial released sugars concentration obtained from sugarcane bagasse to $30.8 \mathrm{gL}^{-1}$ and $32.1 \mathrm{gL}^{-1}$, respectively (Table 6 , footnote). Final bioethanol concentration decreased in all treatments inoculated by irradiated Z. mobilis ATCC 29191 and Sacch. cerevisiae ATCC 7754 subjected to all irradiation doses. The highest final bioethanol concentration obtained by Z. mobilis ATCC 29191 irradiated at 100 Gy on sugarcane bagasse hydrolyzed for 30 min was $2.9 \mathrm{gL}^{-1}$. In this treatment, the bioethanol yield, conversion coefficient and sugar utilization efficiency were $9.4 \%(\mathrm{w} / \mathrm{w}), 38.2 \%(\mathrm{w} / \mathrm{w})$ and $24.7 \%(\mathrm{w} / \mathrm{w})$, respectively.

The highest final bioethanol concentration was $6.8 \mathrm{gL}^{-1}$, which was obtained by Sacch. cerevisiae ATCC 7754 irradiated at $300 \mathrm{~Gy}$ on sugarcane bagasse hydrolyzed for $60 \mathrm{~min}$ and the bioethanol yield and conversion coefficient and sugar utilization efficiency were $21.2 \%(\mathrm{w} / \mathrm{w}), 45 \%(\mathrm{w} / \mathrm{w})$ and $47 \%(\mathrm{w} / \mathrm{w})$, respectively. Increasing the irradiation dose over 300 Gy greatly decreased the final bioethanol concentration. The highest cells count was recorded in the nonirradiated culture of Sacch. cerevisiae $\left(25.6 \times 10^{4} \mathrm{CFU} \mathrm{m}{ }^{-1}\right)$, while it was $16.7 \mathrm{x}$ $10^{4} \mathrm{CFU} \mathrm{ml}^{-1}$ for the same treatment of Z. mobilis ATCC 29191. Similar to these findings, many investigators found that exposing strains of Saccharomyces cerevisiae to lower doses of gamma irradiation (100 - $1000 \mathrm{~Gy})$ increased its growth and its ability of producing ethanol in stress conditions (Abo-Sereh et al., 2006; Edgardo et al., 2008 and Abdel-Fattah et al., 2000).

\section{Acid-hydrolyzed potato peels}

Similar to what have been conducted on sugarcane bagasse, potato peels were used as substrate for bioethanol production after been hydrolyzed using the same set of treatments. Acid hydrolysis of potato peels was performed using 2 and $6 \%$ (v/v) $\mathrm{H}_{2} \mathrm{SO}_{4}$ acid at $100^{\circ} \mathrm{C}$ and $120^{\circ} \mathrm{C}$ and for 30 and 60 min retention time. The neutralized acid-hydrolyzates of potato peels, amended with nutrients, was used as basal media to study the effect of gamma irradiation (doses of $0,100,300$, 500,1000 and $1500 \mathrm{~Gy}$ ) on bioethanol production by either Z. mobilis ATCC 29191 or Sacch. cerevisiae ATCC 7754 incubated for 4 days at $30^{\circ} \mathrm{C}$.

As can be seen in Table 7, acid hydrolysis treatment of potato peels with $2 \%$ (v/v) $\mathrm{H}_{2} \mathrm{SO}_{4}$ at $100^{\circ} \mathrm{C}$ for 30 and $60 \mathrm{~min}$ increased initial sugars concentration from $6.7 \mathrm{gL}^{-1}$ (Table 2) to $10.7 \mathrm{gL}^{-1}$ and $12 \mathrm{gL}^{-1}$, respectively. Accordingly, the final bioethanol concentration significantly increased in all hydrolysis treatments of potato peels.

Irradiation of Z. mobilis ATCC 29191 slightly increased its productivity of bioethanol concentration only at $100 \mathrm{~Gy}$, after which increasing the irradiation greatly decreased the final bioethanol concentration. Sacch. cerevisiae ATCC 7754 (irradiated at $300 \mathrm{~Gy})$ achieved the highest bioethanol concentration $\left(5 \mathrm{gL}^{-1}\right)$ when used on potato peels hydrolyzed for $60 \mathrm{~min}$ of retention time. This treatment, recorded the highest bioethanol yield, $41.7 \%$ (w/w), conversion coefficient, $46.3 \%$ (w/w), and sugar utilization efficiency was $90 \%(\mathrm{w} / \mathrm{w})$. The highest cells count was recorded in the non-irradiated culture of Sacch. cerevisiae ATCC 7754 (29.3 x $10^{4} \mathrm{CFU} \mathrm{ml}{ }^{-1}$ ), while it was $20.7 \times 10^{4} \mathrm{CFU} \mathrm{ml}{ }^{-1}$ for the same treatment of $Z$. mobilis ATCC 29191.

Egypt. J. Microbiol. 49 (2014) 
EFFECT OF GAMA IRRADIATION OF BIOETHANOL...

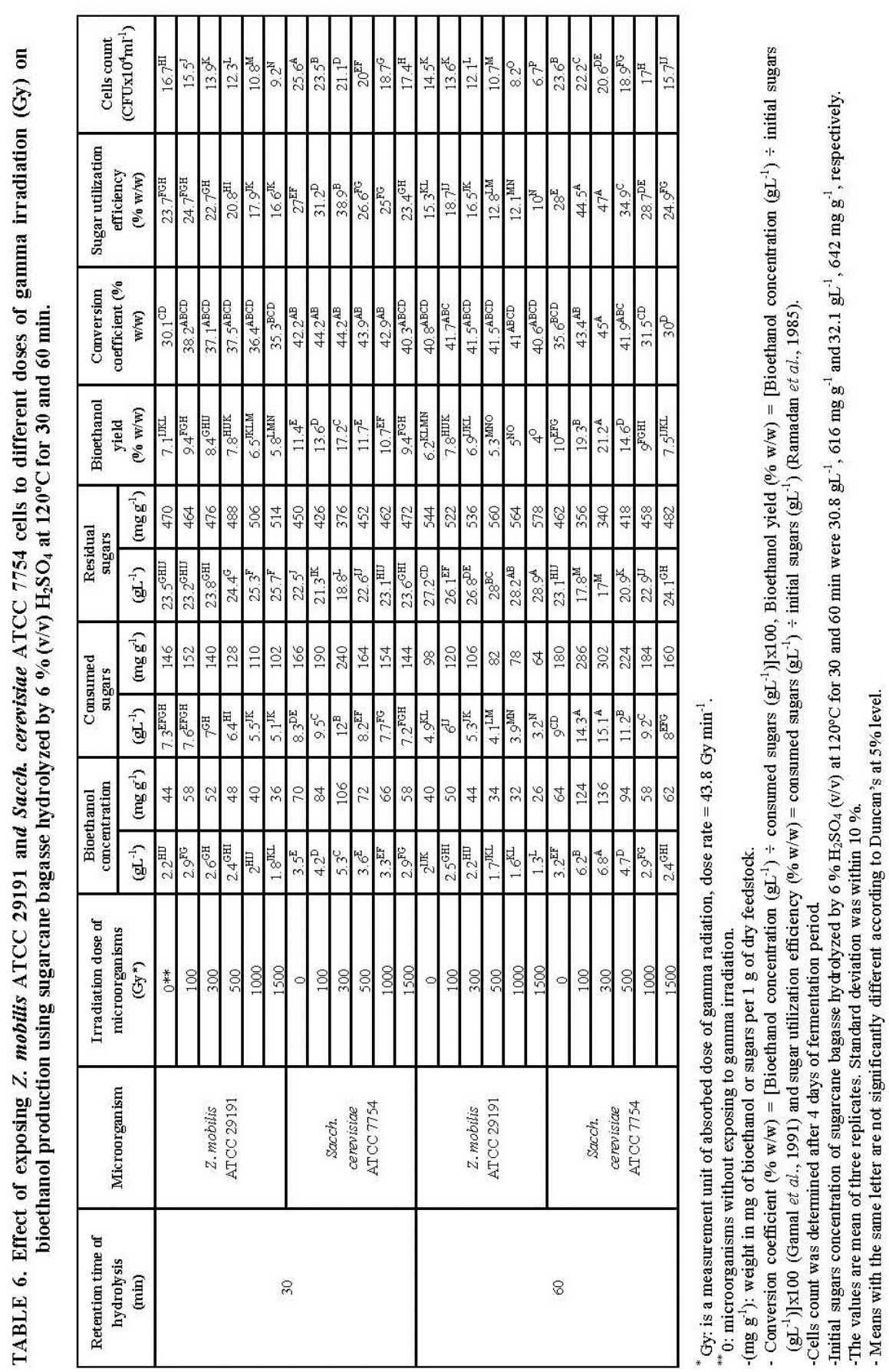

Egypt. J.Microbiol. 49 (2014) 


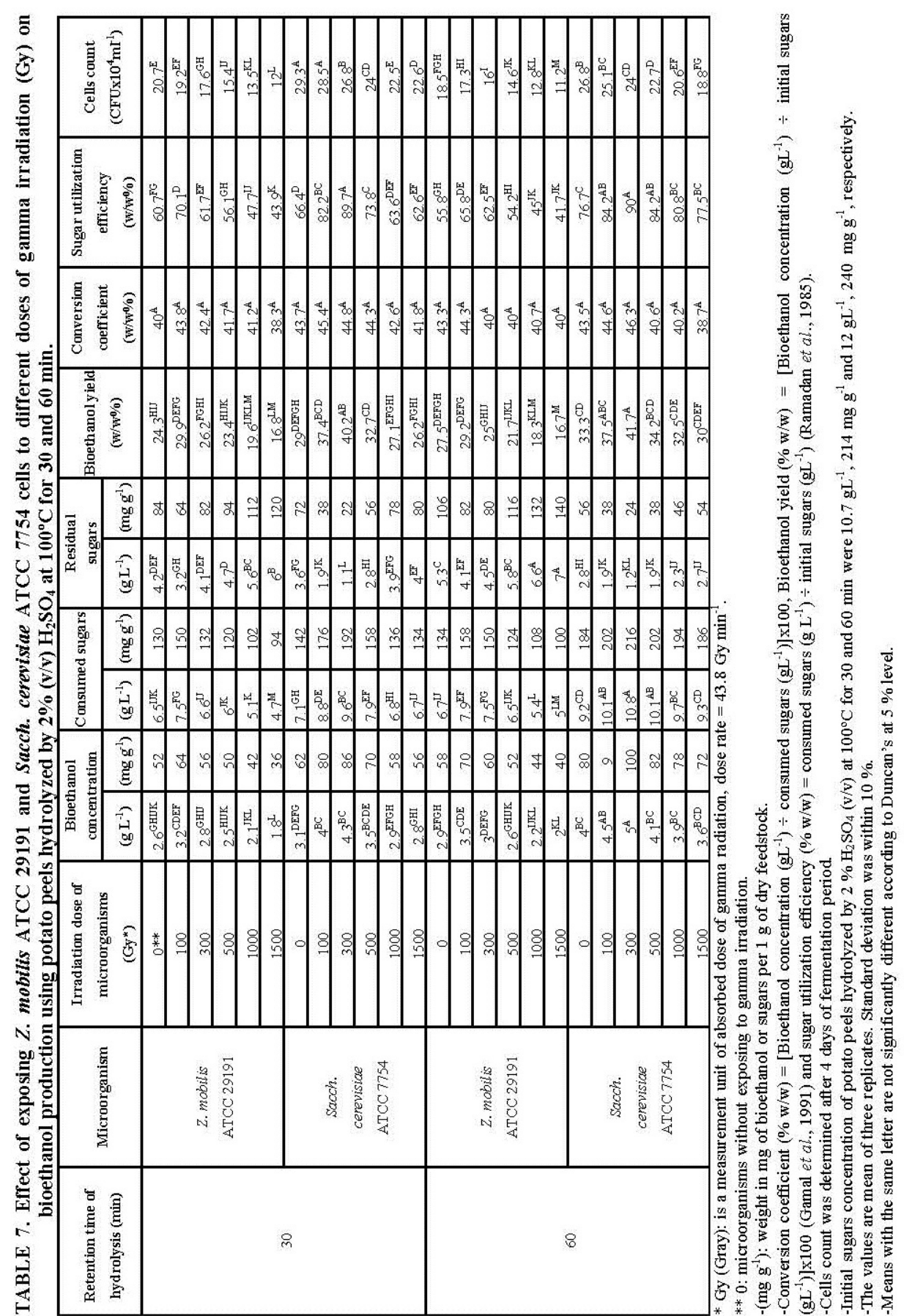


These results are in line with those obtained by Tasić et al. (2009) who reported that acid hydrolysis of potato tuber mash by $1 \mathrm{M} \mathrm{HCl}$ at $1: 1(\mathrm{w} / \mathrm{v})$ ratio, at $\left(100^{\circ} \mathrm{C}\right)$ for $60 \mathrm{~min}$, gave the highest dextrose equivalent $(94 \%)$ and the best bioethanol yield $\left(31 \mathrm{gL}^{-1}\right)$ in batch fermentation for $18 \mathrm{~h}$ by Sacch. cerevisiae with inoculum rate of $3 \%(\mathrm{w} / \mathrm{v})$.

Resulted presented in Table 8 showed the effect of increasing hydrolysis temperature to $120^{\circ} \mathrm{C}$ using the same acid concentration, i.e. $2 \% \mathrm{H}_{2} \mathrm{SO}_{4}$ (v/v). Results showed hydrolysis of potato peels at $120^{\circ} \mathrm{C}$ for 30 and $60 \mathrm{~min}$ increased the initial sugars concentration from potato peels to $14.6 \mathrm{gL}^{-1}$ and $18.1 \mathrm{gL}^{-1}$, respectively, and logically, the final bioethanol concentration significantly increased in all hydrolysis treatments. The highest bioethanol concentration obtained by $Z$. mobilis ATCC 29191 was $3.8 \mathrm{gL}^{-1}$, which was obtained from 100 Gy treatment on potato peels hydrolyzed for $30 \mathrm{~min}$ and $4.3 \mathrm{gL}^{-1}$, obtained from $300 \mathrm{~Gy}$ treatment used on potato peels hydrolyzed for $60 \mathrm{~min}$. On the other hand, Sacch. cerevisiae ATCC 7754 had better results, that is when irradiated at $300 \mathrm{~Gy}$, it produced bioethanol concentration of $6 \mathrm{gL}^{-1}$, from potato peels hydrolyzed for $30 \mathrm{~min}$ and $6.5 \mathrm{gL}^{-1}$, from potato peels hydrolyzed for $60 \mathrm{~min}$. In the last treatment, bioethanol yield, conversion coefficient and sugar utilization efficiency were $35.9 \%(\mathrm{w} / \mathrm{w})$, $44.8 \%(\mathrm{w} / \mathrm{w})$ and $80.1 \% \mathrm{w} / \mathrm{w}$, respectively. Bioethanol concentration decreased in the culture of Z. mobilis ATCC 29191 (irradiated more than 100 and $300 \mathrm{~Gy}$ ) on potato peels hydrolyzed for 30 and $60 \mathrm{~min}$.

As in previous experiment, irradiation had negative effect on cell counts of both organisms that was recorded in the non-irradiated culture of Sacch. cerevisiae ATCC $7754\left(28.9 \times 10^{4} \mathrm{CFU} \mathrm{m}{ }^{-1}\right)$, while it was $18.3 \times 10^{4} \mathrm{CFU} \mathrm{ml}^{-1}$ for the same treatment of Z. mobilis ATCC 29191. In this respect, Mehdikhani et al. (2011) found that Sacch. cerevisiae cells exposed to 100 Gy of $\gamma$-irradiarion produced a high yield of bioethanol $(23.50 \% \mathrm{w} / \mathrm{v})$ at $42^{\circ} \mathrm{C}$ compared with the non-irradiated strain.

Results of hydrolyzing potato peels with $6 \%$ (v/v) $\mathrm{H}_{2} \mathrm{SO}_{4}$ at $100^{\circ} \mathrm{C}$, presented in Table 9, showed that running hydrolysis for 30 and $60 \mathrm{~min}$ increased the initial released sugars concentration obtained to $21.3 \mathrm{~g} \mathrm{~L}^{-1}$ and $24 \mathrm{~g}$ $\mathrm{L}^{-1}$, respectively. Final bioethanol concentration increased in all treatments inoculated with irradiated Z. mobilis ATCC 29191 and Sacch. cerevisiae ATCC 7754. The highest final bioethanol concentration obtained by Z. mobilis ATCC $29191\left(5.7 \mathrm{gL}^{-1}\right)$ was in the treatment irradiated at $100 \mathrm{~Gy}$ on potato peels hydrolyzed for $60 \mathrm{~min}$. In this treatment, the bioethanol yield and conversion coefficient were $23.8 \%(\mathrm{w} / \mathrm{w})$ and $45.2 \%$ (w/w), respectively. Exposing $Z$. mobilis ATCC 29191 to irradiation above 100 Gy significantly decreased its productivity of bioethanol, whether hydrolysis was run for $30 \mathrm{~min}$ or $60 \mathrm{~min}$. The highest final bioethanol concentration obtained by Sacch. cerevisiae ATCC $7754\left(7.5 \mathrm{gL}^{-1}\right)$ was in the treatment irradiated at $300 \mathrm{~Gy}$ on potato peels hydrolyzed for $60 \mathrm{~min}$. In this treatment, the bioethanol yield and conversion coefficient were $31.3 \%(\mathrm{w} / \mathrm{w})$ and $45.7 \%(\mathrm{w} / \mathrm{w})$, respectively. Increasing the irradiation dose to Sacch. cerevisiae ATCC 7754 over 300 Gy decreased greatly the final bioethanol concentration. The highest cells count was recorded in the non-irradiated culture of Sacch. cerevisiae ATCC 7754 (26.7 x 10 $\left.0^{4} \mathrm{CU} \mathrm{ml}^{-1}\right)$, while it was $16.9 \times 10^{4} \mathrm{CFU} \mathrm{ml}{ }^{-1}$ for the same treatment of $Z$. mobilis. 


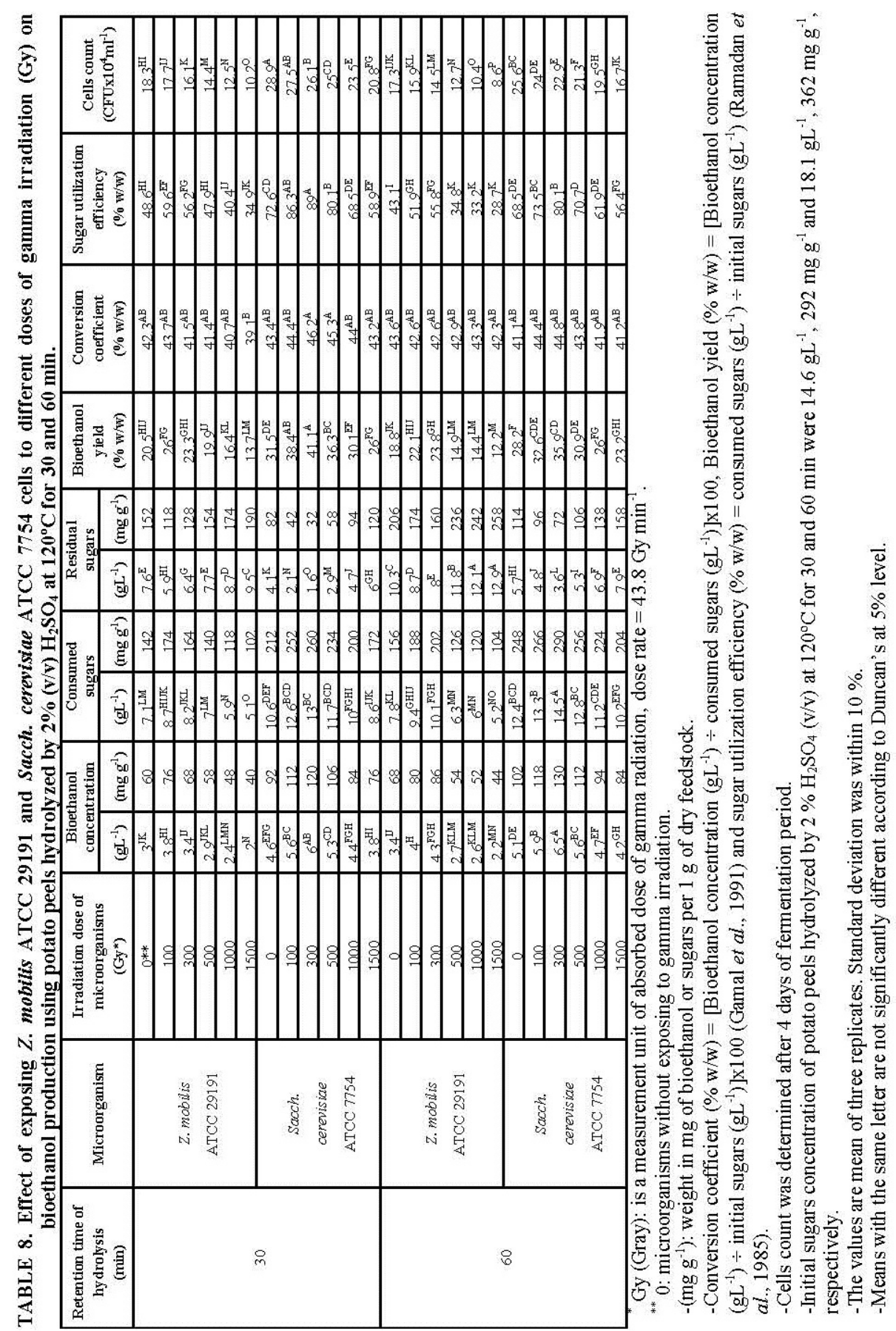

Egypt. J. Microbiol. 49 (2014) 


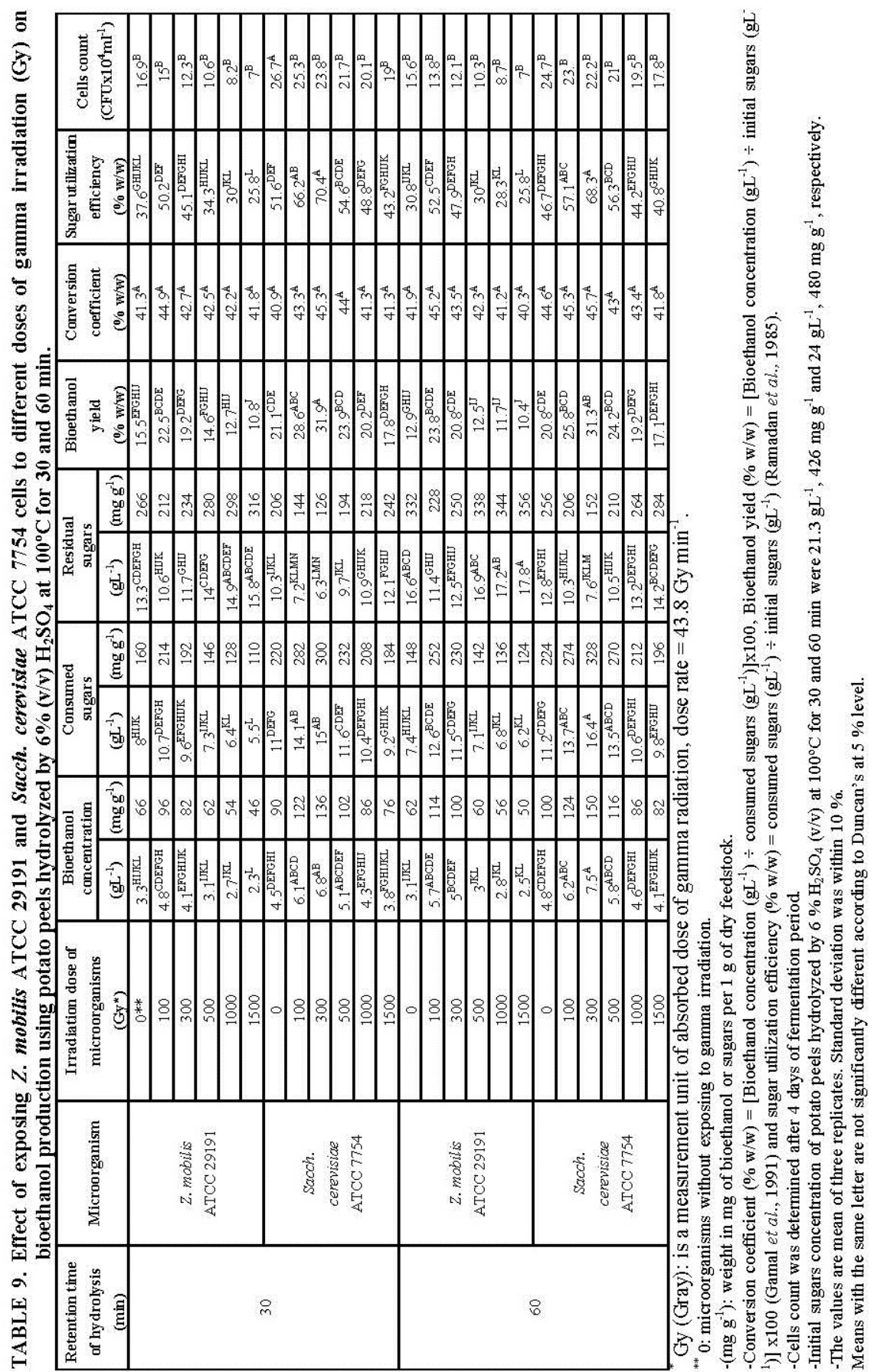

Egypt. J.Microbiol. 49 (2014) 
Data presented in Table 10 show the effect of increasing hydrolysis temperature to $120^{\circ} \mathrm{C}$. Hydrolysis using $6 \%(\mathrm{v} / \mathrm{v}) \mathrm{H}_{2} \mathrm{SO}_{4}$ at $120^{\circ} \mathrm{C}$ for 30 and 60 min increased the initial released sugars concentration obtained from sugarcane bagasse to $25.7 \mathrm{gL}^{-1}$ and $28.6 \mathrm{gL}^{-1}$, respectively (compared with the hydrolysis with $6 \%(\mathrm{v} / \mathrm{v}) \quad \mathrm{H}_{2} \mathrm{SO}_{4}$ at $\left.100^{\circ} \mathrm{C}\right)$. However, final bioethanol concentration decreased in all treatments inoculated by Z. mobilis ATCC 29191 and Sacch. cerevisiae ATCC 7754 subjected to all irradiation doses.

The highest final bioethanol concentration obtained by Z. mobilis ATCC 29191 was $3.4 \mathrm{gL}^{-1}$ from irradiation culture at $100 \mathrm{~Gy}$ on potato peels hydrolyzed for $30 \mathrm{~min}$. In this treatment, the bioethanol yield, conversion coefficient and sugar utilization efficiency were $13.2 \%(\mathrm{w} / \mathrm{w}), 41.5 \%(\mathrm{w} / \mathrm{w})$ and $31.9 \%(\mathrm{w} / \mathrm{w})$, respectively. Comparatively, the highest final bioethanol concentration obtained by Sacch. cerevisiae ATCC 7754 was $5.6 \mathrm{gL}^{-1}$ from irradiated culture at $500 \mathrm{~Gy}$ on potato peels hydrolyzed for $60 \mathrm{~min}$. In this treatment, the bioethanol yield, conversion coefficient and sugar utilization efficiency were $19.6 \%(\mathrm{w} / \mathrm{w}), 46.3 \%$ $(\mathrm{w} / \mathrm{w})$ and $42.3 \%(\mathrm{w} / \mathrm{w})$, respectively. Increasing the irradiation dose over 100 for Z. mobilis ATCC 29191 and over 300 Gy for Sacch. cerevisiae significantly decreased the final bioethanol concentration. The highest cell counts for Sacch. cerevisiae ATCC 7754 was in non-irradiated culture which was $23 \times 10^{4} \mathrm{CFU}$ $\mathrm{ml}^{-1}$, while it was $13.6 \times 10^{4} \mathrm{CFU} \mathrm{ml}{ }^{-1}$ for the non-irradiated treatment of $Z$. mobilis ATCC 29191.

From the aforementioned results, several points could be noticed. Treatment of gamma irradiation to Sacch. cerevisiae ATCC 7754 or Z. mobilis ATCC 29191, prior to inoculation of the neutralized acid hydrolyzates of either sugarcane bagasse or potato peels (Tables 3-10), significantly increased the final bioethanol concentration compared with the treatment of non-irradiated organisms and non-hydrolyzed feedstock (Table 2). Apparently, exposing both Z. mobilis ATCC 29191 and Sacch. cerevisiae ATCC 7754 to gamma irradiation helped these microorganisms to tolerate the toxic residues formed in the feedstock acid hydrolyzates, which was reflected on increasing the final bioethanol concentration.

The most favorable treatment of sugarcane bagasse was using the irradiated Sacch. cerevisiae at $300 \mathrm{~Gy}$ on the neutralized acid hydrolyzates using $2 \%(\mathrm{v} / \mathrm{v})$ $\mathrm{H}_{2} \mathrm{SO}_{4}$ at $120^{\circ} \mathrm{C}$ for 60 min (Table 4). This treatment achieved a maximum final bioethanol concentration of $10.3 \mathrm{gL}^{-1}$ (equivalent to $206 \mathrm{mg} \mathrm{g}^{-1}$ ) which represents 2.5 fold of final bioethanol concentration obtained by non-irradiated strain from nonhydrolyzed sugarcane bagasse. While the best treatment in case of potato peels was using the irradiated Sacch. cerevisiae ATCC 7754 at 300 Gy on the neutralized acid hydrolyzates using $6 \%$ (v/v) $\mathrm{H}_{2} \mathrm{SO}_{4}$ at $100^{\circ} \mathrm{C}$ for $60 \mathrm{~min}$ (Table 9), which achieved a maximum final bioethanol concentration of $7.5 \mathrm{gL}^{-1}\left(150 \mathrm{mg} \mathrm{g}^{-1}\right)$, representing 3.4 fold of the final bioethanol concentration obtained by non-irradiated strain from nonhydrolyzed potato peels. 
EFFECT OF GAMA IRRADIATION OF BIOETHANOL..

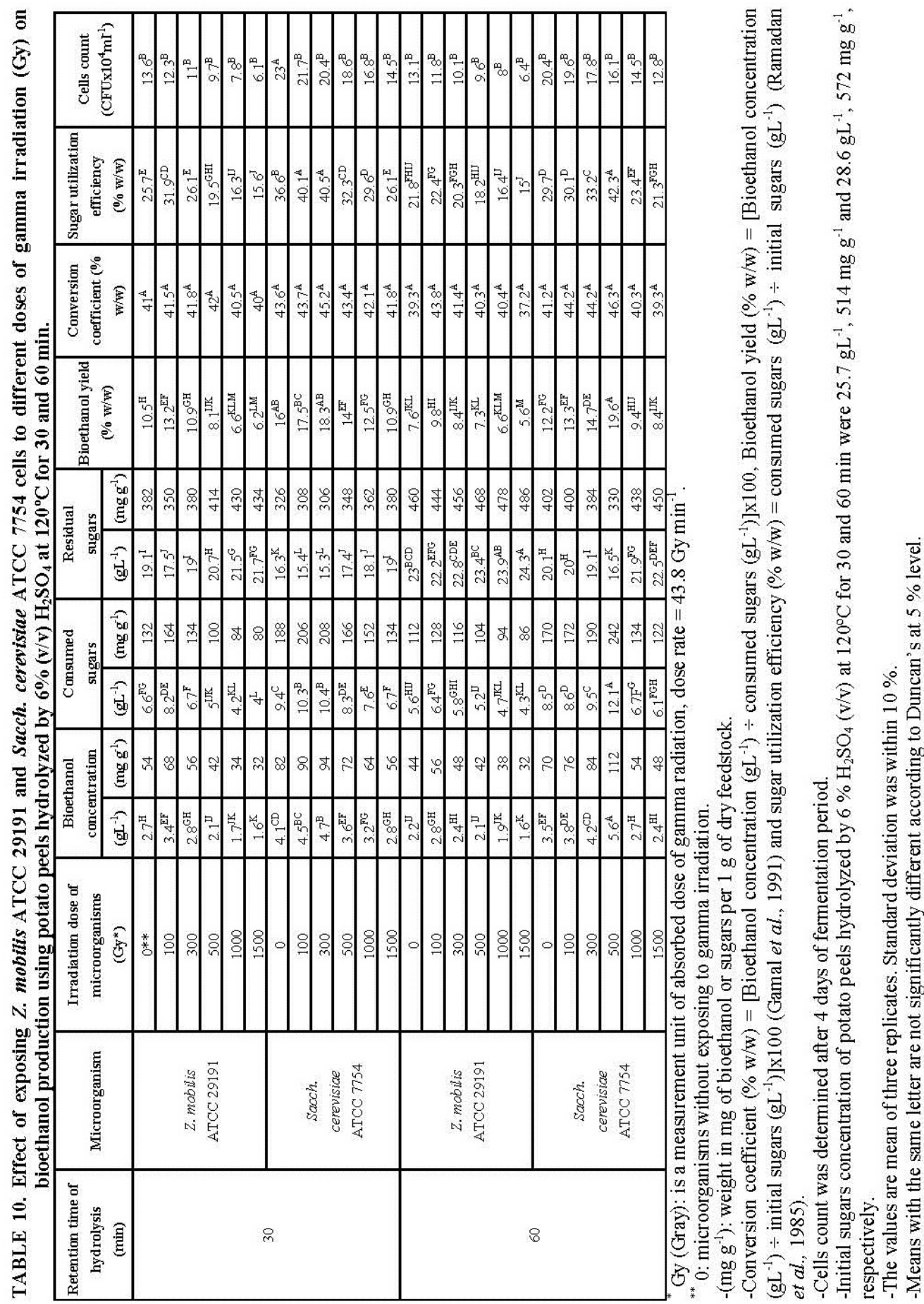

Egypt. J.Microbiol. 49 (2014) 


\section{Conclusions}

As mentioned earlier, dilute acid hydrolysis led to increase the total sugars (initial sugars) from both sugarcane bagasse and potato peels compared with nonhydrolyzed feedstock. The highest concentrations of total sugars were $32.1 \mathrm{gL}^{-1}$ (equivalent to $642 \mathrm{mg} \mathrm{g}^{-1}$ ) from sugarcane bagasse and $28.6 \mathrm{~g} \mathrm{~L}^{-1}$ (equivalent to $572 \mathrm{mg} \mathrm{g}^{-1}$ ) from potato peels, both obtained from hydrolysis by $6 \%(\mathrm{v} / \mathrm{v}) \mathrm{H}_{2} \mathrm{SO}_{4}$ at $120^{\circ} \mathrm{C}$ for $60 \mathrm{~min}$. It is apparent from previous irradiation results to microorganisms, that they were sensitive to high levels of irradiation in general. Z. mobilis ATCC 29191 were more sensitive to irradiation and toxic compounds than Sacch. cerevisiae ATCC 7754. Therefore, further experiments will be conducted and published in a second manuscript to determine the effect of irradiation, in addition to acid hydrolysis, of feedstock using irradiated microorganisms, which showed the highest bioethanol productivity obtained from current experiments. The production of bioethanol using a co-culture of $Z$. mobilis ATCC 29191 and Sacch. cerevisiae ATCC 7754 will also be tested.

\section{References}

Abdel-Fattah, W.R., Fadil, M., Nigam, P. and Banat, I.M. (2000) Isolation of thermotolerant ethanologenic yeasts and use of selected strains in industrial scale fermentation in an Egyptian distillery. Biotechnol. Bioeng. 68, 531-535.

Abo-Sereh, N.A., Soliman, E.A.M. and Abd El-Khalek, B.A. (2006) Mutation Induction for Genetic Improvement of Saccharomyces boulardii which used as probiotic. Yeast Res. J. Agr. Biol. Sci. 2, 478-482.

Abo-State, Mervat A., Ragab, A.M., El-Gendy, N.Sh., Farahat, Laila A. and Madian,

Hekmat R. (2013) Effect of different pretreatments on Egyptian sugarcane bagasse saccharification and bioethanol production. Egypt J. Petrol. 22, 161-167.

Aguilar, R., Ramírez, J.A., Garrote, G. and Vázquez, M. (2002) Kinetic study of the acid hydrolysis of sugarcane bagasse. J. Food Eng. 55, 309-318.

Akacha, N., Zehlila, A., Mejri, S., Taieb, J. and Mohamed, G. (2008) Effect of gamma ray on activity and stability of alcohol dehydrogenase from Saccharomyces cerevisiae. Biochem. Eng. J. 40, 184-188.

Al-Sudany, A., Wasan, M.Z. and Al-Aubeidi, Hind J.A. (2010) Detection of gamma radiation effect induced by Cobelt-60 on Escherichia coli cells. J. Al-Nahrain Univ. 13, 129-133.

Arapoglou, D., Varzakas, T., Vlyssides, A. and Israilides, C. (2010) Ethanol production from potato peel waste (Ppw). Waste Manage. 30, 1898-1902.

Atia, K.S. (2005) Co-immobilization of cyclo-hexanone mono-oxygenase and glucose-6phosphate dehydrogenase onto polyethylenimine-porous agarose polymeric composite using $\gamma$-irradiation to use in biotechnological processes. Radiat. Phys. Chem. 73, 91-99. 
Carvalho, N.L. (2009) Dilute acid and enzymatic hydrolysis of sugarcane bagasse for biogas production. Master Thesis. Department of Chemical and Biological Engineering, Instituto Superior Técnico, Lisbon, Portugal

Chakravarty, B. and Sen, S. (2001) Enhancement of regeneration potential and variability by $\gamma$-irradiation in cultured cells of Scilla indica. Biologia Plantarum, 44, 189-193.

Crowell, E.A. and Ough, C.S. (1979) A Modified procedure for alcohol determination by dichromate oxidation. Am. J. Enol. Viticult. 30, 61-63.

Davis, Linda, Rogers, P. Pearce, J. and Peiris, P. (2009) Evaluation of zymomonasbased ethanol production from a hydrolysed waste starch stream. Biomass Bioenergy, 30, 809-814.

Dubois, M., Gilles, K.A., Hamilton, J.K., Rebers, P.A. and Smith, F. (1956) Colorimetric method for determination of sugars and related substances. Anal. Chem. 28, 350-356.

Duncan, D.B. (1955) Multiple ranges and multiple F test. Biometrics, 11, 1-42.

Edgardo, A., Parra, C., Manuel, R., Juanita, F. and Jaime, B. (2008) Selection of thermotolerant yeast strains Saccharomyces cerevisiae for bioethanol production. Enzyme Microbial. Technol. 2, 1-7.

Ferdian, W., Cheng, C., Kao, W., Lee, D.B. and Chang, J. (2012) Cellulosic ethanol production performance with SSF and SHF processes using immobilized Zymomonas mobilis. Appl. Energy, 100, 19-26.

Gamal, Rawia F., Nassar, Fatma R., Abd El-Hady, Hemmat M. and El-Sawy, M. (1991) Glycerol production by osmotolerant yeast strain using fermentor as fed batch and continuous culture techniques. Annal. Agric. Sci., Ain Shams University, 36, 319-421.

George, J., Carlos, M., Isaias, B., Souto, Maria A., Henrique, M. and Cesar, A. (2011) Dilute mixed-acid pretreatment of sugarcane bagasse for ethanol production. Biomass Bioenergy, 35, 663-670.

Grecz, N., Rowley, D.B. and Matsuyama, A. (1983) The action of radiation on bacteria and viruses. In: "Preservation of Food by Ionizing Radiation", Josephson Es; Peterson Ms (Ed). Vol. Ii. pp. 167-218. Boca Raton; Fl; Crc Press.

Gunasekaran, P. and Chandra, K.R. (2007) Ethanol fermentation Technology: Zymomonas mobilis. pp. 1-22. Madurai Kamary University, Madurai, India,

Jacobsen, S.E. and Wyman, C.E. (2002) Xylose monomer and oligomer yields for uncatalyzed hydrolysis of sugarcane bagasse hemicellulose at varying solids concentration. Ind. Eng. Chem. Res. 41, 1454-1461.

Karimi, K., Emtiazi, G. and Taherzadeh, M.J. (2006) Ethanol production from diluteacid pretreated rice straw by simultaneous saccharification and fermentation with Mucor indicus; Rhizopus oryzae and Saccharomyces cerevisiae. Enzyme Microbial. Technol. 40, 138-44. 
Limayem, A. and Steven, C.R. (2012) Lignocellulosic biomass for bioethanol production: current perspectives; potential issues and future prospects (Review). Prog. Energy Combust. Sci. 38, 449-467.

Mehdikhani, P., Mahmoud, B.R. and Hrachya, H. (2011) Screening of Saccharomyces cerevisiae for high tolerance of ethanol concentration and temperature. African J. Microbiol. Res. 5, 2654-2660.

Osterholm, M.T. and Norgan, A.P. (2004) The Role of irradiation in food safety. New England J. Med. 350, 1898-1901.

Pak, S.C. and Simon, M.L. (2004) A Method for routine measurements of total sugar and starch content in woody plant tissues. Tree Physiol. 24, 1129-1136.

Pattana, L., Thani, A., Leelavatcharamas, V. and Laopaiboon, L. (2010) Acid hydrolysis of sugarcane bagasse for lactic acid production. Bioresour. Technol. 101, 1036-1043.

Ramadan, E.M., El-Sawy, M., Gamal, Rawia F. and Abd El-Hady, Hemmat M. (1985) Growth parameters of yeast grown on agricultural residues using shake flask as a batch culture. Annals Agric. Sci., Ain Shams University, 30, 25-45.

SAS (1996) "Statistical Analysis System, SAS User's Guide”: Statistics. SAS Institute. Inc. Editors, Cary, NC.

Stuart, N.W. (1936) Adaptation of the micro-Kjeldahl method for the determination of nitrogen in plant tissues. Plant Physiol. 11, 173-179.

Swings, J. and Deley, J. (1977) The Biology of Zymomonas. Bact. Reviews, 41, 1-46.

Talyour, J. (1962) The estimation of numbers of bacteria by tenfold dilution series. $J$. Appl. Bacteriol. 25, 54-56.

Tasić, M.B., Konstantinović, B.V., Lazić, M.L. and Veljković, V.B. (2009) The acid hydrolysis of potato tuber mash in bioethanol production. Biochem. Engineering J. 43, 208-211.

Thornley, M.J. (1963) Radiation resistance among bacteria. J. Appl. Bacteriol. 26, 334-345.

Tiessen, H. and Moir, J.O. (1993) Total and organic carbon. In: "Soil Sampling and Methods of Analysis”, M.E. Carter (Ed.), pp. 187-211. Lewis Publishers, Ann Arbor, MI.

Wickerham, L.J. (1946) A critical evaluation of the nitrogen assimilation tests commonly used in the classification of yeasts. J. Bacteriol. 52, 293-301. 


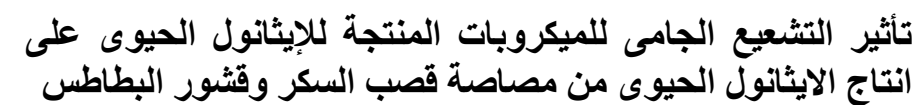

أحمد عبد الوهاب عبد الحافظ ، طارق سعيد الطيب ، طارق محمود المنجى" ومروة

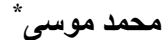

قسم الميكروبيولوجيا الزر اعية ـ كلية الزر اعة ـ جامعة عين شمس - شبر ا الخيمة

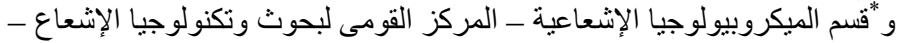

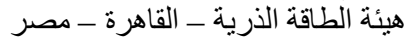

تم اجراء هذا البحث لدراسة انتاج الايثانول الحيوى من المخلفات الزراعية

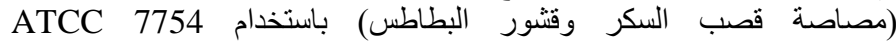
Zymomonas mobilis ATCC 29191 و Saccharomyces cerevisiae

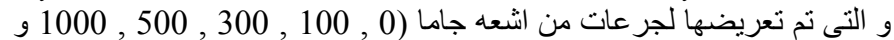

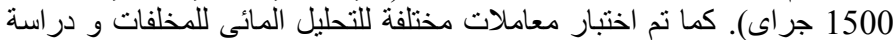

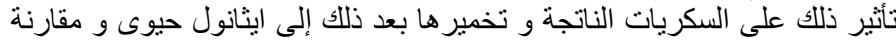

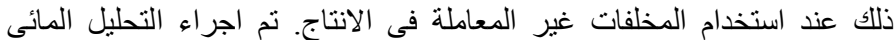

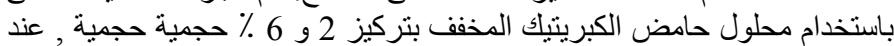

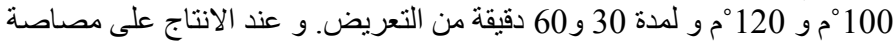

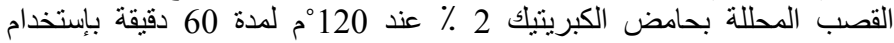
مزر عة ال Sacch. cerevisiae ATCC 7754 المشععة عند 300 جراى كان كان

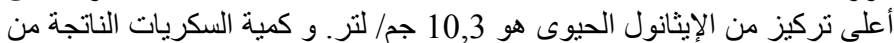

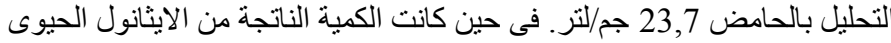

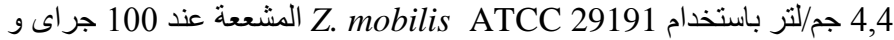
تحت نفس الظروف المذكورة أعلاه. أعلى تركيز للايثانول الحيوى متحفية عندل عليه

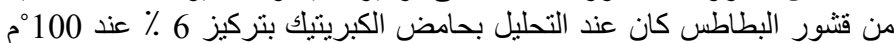
لمدة 60 دقيقة بإستخدام 7754 Sacch. cerevisiae ATCC

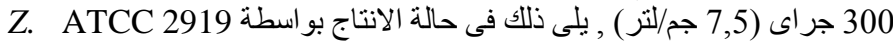
mobilis

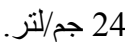

